\title{
A Small Spherical Virus Associated with the Ajinashika Disease of Koshu Grapevine
}

\author{
Shigetou NambA*, Shuichi Yamashita*, Yoji DoI* \\ and Kiyoshi YorA*
}

難波成任*・山下修一* ·土居養二*・與良 清* : 甲州ブドウの味無果病で見出される小球形ウイルス

Ajinashika disease of Koshu grapevine (Vitis vinifera Linn. cv. Koshu) has been observed by grapevine growers to occur in Yamanashi prefecture for about ten years. Ajinashika, a Japanese word, means unpalatable fruits of low sugar content. Diseased fruits cannot be used as green fruits or as the material for wine. The disease has been said to occur only on Koshu grapevine, but recently it was found on Delaware, Kyoho, and some other varieties. No definite conclusion has been drawn concerning the etiology of the disease.

A small spherical virus was detected in leaves and fruits from Koshu grapevine trees affected by the disease. The virus was shown to be always associated with the disease. Since the virus was different from any virus so far reported from grapevine, we designated it the grapevine ajinashika virus (GAV)**.

Symptoms of the disease on Koshu grapevine are not evident, and diseased trees produce as much fruits as healthy ones. Matured fruits from diseased trees, however, appear to be slightly light-colored, and their sugar content is very low (ca. $12 \%$ ) as compared with that of normal fruits (ca. $17 \%$ ). It is noteworthy that diseased trees show no visible symptoms and can be recognised only by a marked decline of sugar content in their fruits.

Leaves and fruits were collected from diseased trees in commercial vineyards in Yamanashi prefecture in 1976 and 1977. They were homogenized in $0.05 \mathrm{M}$ phosphate buffer ( $\mathrm{pH} 7.8$ ) containing $0.01 \mathrm{M}$ EDTA and $2 \%$ Triton X-100. The homogenate was filtered through several layers of cheesecloth, and to the filtrate was added chloroform at a concentration of $20 \%$. The resultant solution was centrifuged by two cycles of differential centrifugation. The final pellet was suspended in $0.05 \mathrm{M}$ phosphate buffer to make the partially purified virus preparation. The presence of small spherical particles of about $28 \mathrm{~nm}$ in diameter was shown in the preparation (Fig. 1). The control preparation from healthy trees by the same procedure did not contain such particles.

Leaves, peduncles, and fruit cores were collected from diseased trees at various times during summer and autumn. They were fixed in $5 \%$ glutaraldehyde, postfixed in $1 \%$ osmium tetroxide, and embedded in Epon 812. Thin sections were cut, stained with uranyl acetate and lead citrate, and examined under an electron microscope. Controls were prepared from healthy trees in the same way. In thin sections of leaves, peduncles, and fruit cores from diseased trees, phloem necrosis and accumulation of starch grains were observed in mesophyll cells (Fig. 4). These two pathological changes were thought to be internal symptoms characteristic of the ajinashika disease. In addition, small spherical particles of about $26 \mathrm{~nm}$ in diameter

* Faculty of Agriculture, University of Tokyo, Bunkyo-ku, Tokyo 113, Japan

東京大学農学部

** ブドウ味無果ウイルス 
were found in phloem cells. They seemed to be the same particles as observed in the partially purified virus preparation. The particles sometimes existed as aggregated masses or crystallines in the cytoplasm, and in nuclei and vacuoles, of sieve tubes, phloem companion cells, or phloem parenchyma cells showing necrosis (Figs. 5-8). The distance from center to center of two neighboring particles in a crystalline array was about $26 \mathrm{~nm}$. The particles were often observed to exist in a line along concentric membrane layers forming spherical bodies. As the phloem necrosis advanced, these bodies appeared to collapse gradually (Fig. 10). Inclusions of protein nature were sometimes observed together with aggregated masses of the particles (Fig. 11). Such small spherical particles were never found in healthy controls.

Leaves and fruits from diseased trees were ground in $0.1 \mathrm{M}$ phosphate buffer

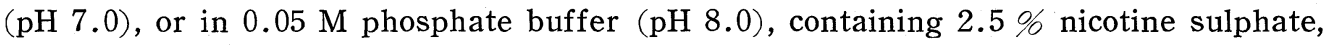
and crude sap was prepared. Sap inoculations were attempted to transmit the virus to young seedlings of Chenopodium amaranticolor, C. quinoa, Cucumis sativa, Cucurbita moschata, Datura stramonium, Lactuca sativa, Lycopersicon esculentum, Nicotiana glutinosa, N. rustica, N. tabacum (Samsun and White Burley), Petunia hybrida, and Vigna sesquipedalis, but successful transmission was not accomplished.

From these results, it is likely that the small spherical particles observed here are virus particles associated with the ajinashika disease. Yano and Terai (unpublished data) succeeded in graft transmission of the disease. Their work together with ours strongly suggests that the disease is caused by a virus, the grapevine ajinashika virus. More careful studies are now in progress to reach the final conclusion.

(Received November 17, 1978)

\section{Explanation of plates}

Fig. 1. Negatively stained GAV particles in partially purified preparation. Bar represents $100 \mathrm{~nm}$.

Fig. 2. Phloem necrosis in phloem elements. Bar represents $2,000 \mathrm{~nm}$.

Fig. 3. Accumulation of starch grains in mesophyll cells. Bar represents 2,000 nm.

Fig. 4. (a) GAV particles in phloem parenchyma cell. Bar represents $250 \mathrm{~nm}$.

(b) High magnification of (a). Bar represents $30 \mathrm{~nm}$.

Fig. 5. Aggregated masses of GAV particles in phloem companion cell. Bar represents 300 nm.

Fig. 6. Crystallines of GAV particles in phloem parenchyma cell. Bar represents 1,000 nm.

Fig. 7. Crystallines of GAV particles in phloem companion cell. Bar represents $200 \mathrm{~nm}$.

Fig. 8. (a) Crystallines of GAV particles in phloem companion cell showing necrosis. Bar represents $2,000 \mathrm{~nm}$.

(b) High magnification of (a). Bar represents $150 \mathrm{~nm}$.

Fig. 9. Concentric membrane layers containing GAV particles in phloem parenchyma cell. Bar represents $1,000 \mathrm{~nm}$.

Fig. 10. Concentric membrane layers containing GAV particles in phloem parenchyma cell showing necrosis. Bar represents $500 \mathrm{~nm}$.

Fig. 11. Inclusions of protein nature and GAV particles in phloem parenchyma cell.

(a) Presence of GAV particles in inclusions. Bar represents $500 \mathrm{~nm}$.

(b) Inclusion surrounded by membrane layers. Bar represents $200 \mathrm{~nm}$.

c : crystalline of GAV particles; $\mathrm{cw}$ : cell wall; cy : cytoplasm; $\mathrm{m}$ : membrane layers;

$\mathrm{p}$ : inclusion of protein nature; $\mathrm{s}$ : starch grain; $\mathrm{v}: \mathrm{GAV}$ particles; vac : vacuole 

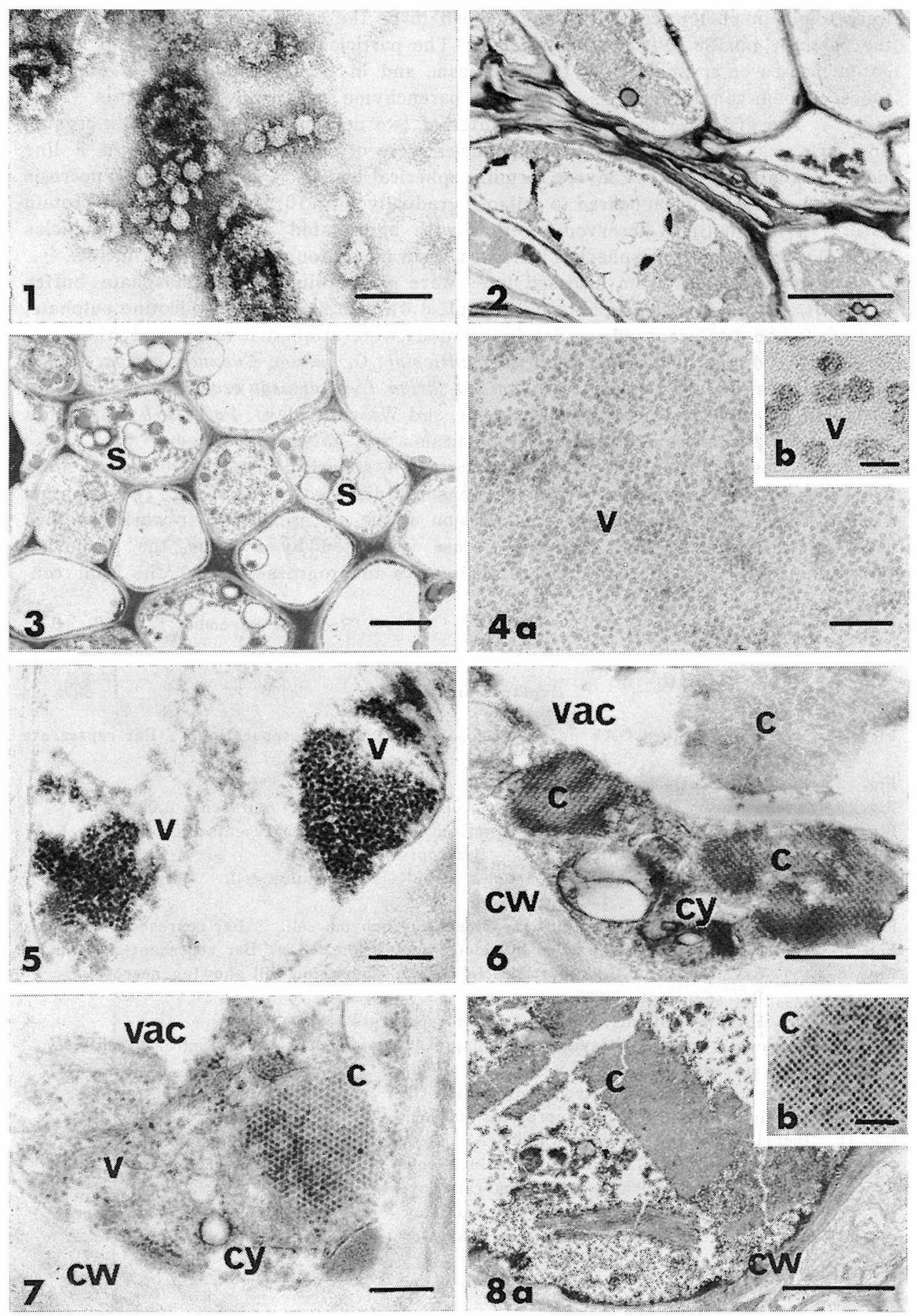


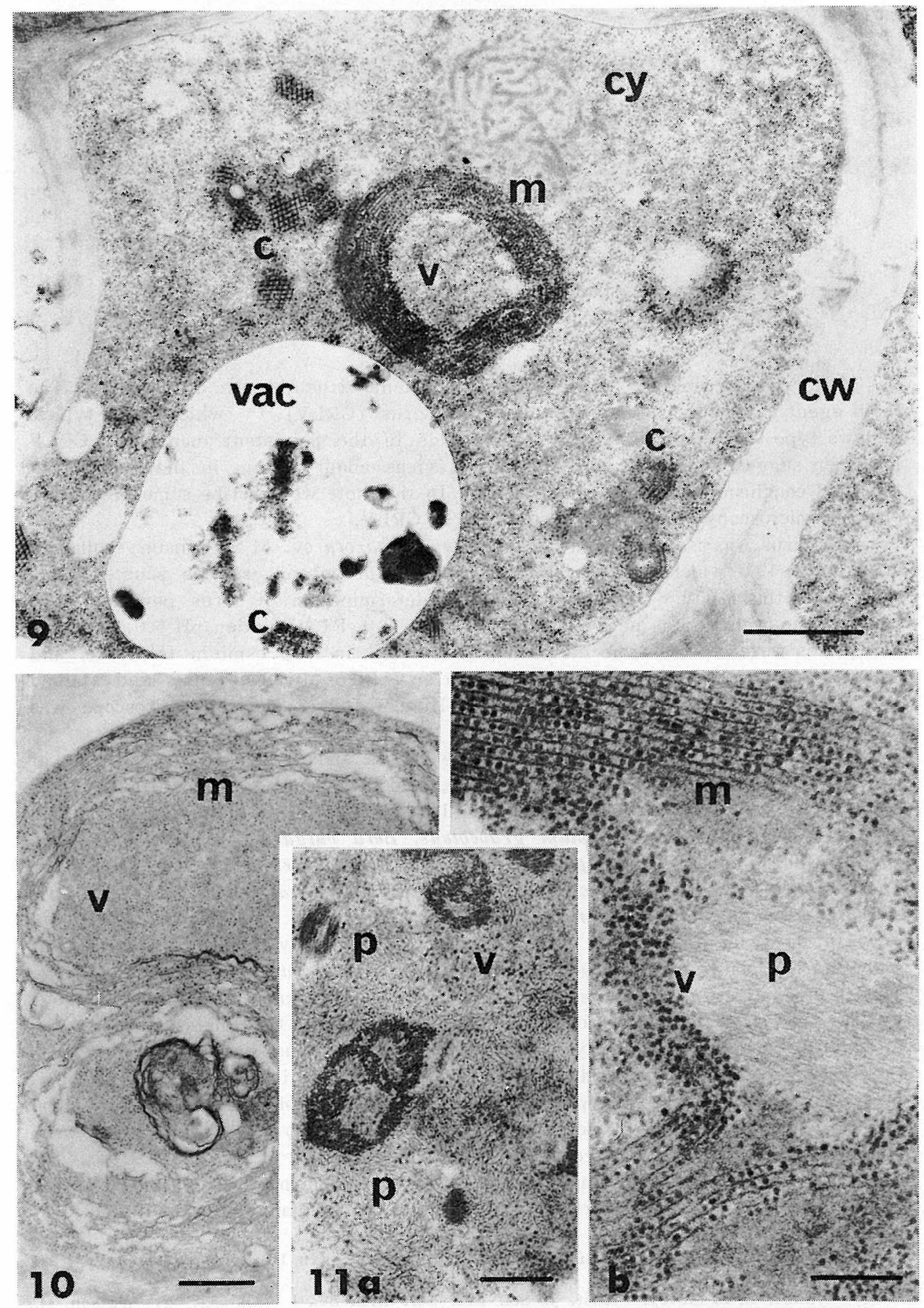

